\title{
WHAT LABOUR MARKET? A CRITICAL STEM SUPPLY SHORTAGE INVESTIGATION: LITHUANIAN CASE
}

\author{
JOGAILA VAITEKAITIS \\ Vilnius University, Faculty of Philosophy, \\ Department of Educational Sciences. \\ 9/1 Universiteto, LT-01513, Vilnius, Lithuania \\ E-mail address: jogaila.vaitekaitis@fsf.vu.lt \\ ORCID: https://orcid.org/0000-0002-6270-1174
}

\begin{abstract}
Aim. The main objective of this investigation is to explore perceived lack of Lithuanian STEM labour force supply. It is often believed that education systems are the bottleneck of economic growth and that by increasing the supply of STEM (science, technology, engineering, mathematics) graduates, we will get more and better payed jobs. However, growing body of evidence suggests that in many STEM fields there is an adequate supply or even oversupply of STEM majors. Still, technologically advanced capitalist countries advocate more STEM workforce regardless of an overcrowded market. Echoing foreign neoliberal trends, Lithuanian education policy makers are on the same STEM shortage hype-train, and reforms are full steam ahead.

Methods. To explore Lithuanian STEM labour force supply an assessment of STEM graduates' $(n=3720)$ occupational destinations one year after the graduation and average salaries in those professions was conducted using a descriptive statistical analysis.

Results. Findings show that there is no general shortage of STEM labour supply; the majority $(54 \% \mathrm{n}=2023)$ of all recent STEM degree holders in Lithuania do not work in STEM jobs. The majority of graduates usually do not reach national average income one year after graduation.

Conclusions. Persuasion of students to study STEM degrees based on better labour market outcomes is misleading and possibly unethical. The principal theoretical implication of this paper is the acknowledgment that low STEM graduate employment does not necessarily signify a failing education system. Rather, this is an opportunity to look beyond human capital and labour market discourse which, arguably, prevents STEM education from realising its revolutionary potential.
\end{abstract}

Key words: STEM graduates, neoliberalism, labour market, supply shortage, education policy 


\section{INTRODUCTION}

Since the beginning of this century a new acronym entered the educational field - STEM. While this curricular reconfiguration focuses on science, technology, engineering and mathematics and closely echoes Sputnik era educational reforms, this time it is not a race for space, but rather for competitiveness in the globalised market economy. STEM acronym is often heard in the context of curricula reforms, migration, security and most notably, STEM labour shortage. Germany declares that, despite immigrant and refugee influx with STEM degrees, it still lacks nearly 340,000 specialists in engineering and tech jobs (Gillmann, 2018). US President Obama's Council of Advisors on Science and Technology stated that over the next decade, one million additional STEM graduates will be needed (Feder, 2012), followed by US Congress issuing immigration bills and practical training extensions exclusively for foreign STEM undergraduates (US ICE, 2016). Likewise UK Royal Academy of Engineering repeats the STEM labour shortage narrative claiming that UK is facing an engineering skills crisis (Morgan, Kirhy, \& Stamenkovic, 2016). Statements like these are accompanied by education reforms and policy changes all over the world.

A recent European Commission initiated report states that "around $80 \%$ of the 30 countries surveyed describe STEM education as currently a priority area at national level" (Kearney 2015, p. 12). Billions of dollars are dedicated for strengthening and integration of STEM curricula in the US educational public law Every Student Succeeds Act. UK puts forward educational agendas promoting formal and informal STEM education (STEM Learning, 2018). Germany establishes national MINT (STEM) forum in order to promote "quality-oriented and effective STEM education" (National es MINT Forum, 2019). South Korea implements nation-wide policies for integrated curricula named STEAM ( $A$ for Arts integration) (Hong, 2017). Meanwhile, UNESCO urges all countries to empower girls and women by promoting study and careers in STEM fields (Chavatzia, 2017). Educational initiatives, projects and reforms are abundant to the point that it is even called STEMmania (Sanders, 2009). While most of scientific research on STEM education is focused primarily on efficiency of policy implementation or underrepresented group inclusion, little attention has been given to the fundamental ontological, epistemological and axiological presuppositions regarding STEM education.

\section{EDUCATIONAL SHORTCOMINGS OF STEM POLICIES}

Nataly Chesky and Mark Wolfmeyer (2015) tried to understand STEM more deeply and looked into its underlying onto-epistemological and axiological makeup. They analysed US STEM education policy documents and revealed that the main aim prescribed for STEM education is utilitarian (science is portrayed primarily as means to further nations' economic power). This leaves such aims as cognitive (facilitating a high level of understanding) or democratic 
(using science for raising critical awareness, social justice and democratic citizenship) behind. Authors point out that the ontological backbone of STEM knowledge depicted in the documents is absolutist. This renders scientific knowledge as objective "truth" immune to historical, political, and economic contexts (Chesky \& Wolfmeyer, 2015). As could be expected, the epistemological tool offered for obtaining this kind of seeming universal knowledge was traditional didactic teaching (importance of memorisation and drills). Authors express concern that alternative epistemological stances such as constructivism (teaching standard-based science through inquiry) or, transformative pedagogy (recognising the extent to which science and technology are culturally determined, linked with wealth and power distribution or develop one's own views for democratic praxis) were non-significant in the policy documents analysed (Chesky \& Wolfmeyer, 2015). These kinds of onto-epistemological ingredients could lead to curriculum standardisation, high stakes testing and an invitation to "get back to the basics". How these Sputnik era reminiscent educational principles contribute to $21^{\text {st }}$ century skills, critical and creative thinking, collaboration or communication, social perceptiveness, negotiation and persuasion presumably crucial for future workplace (Deming, 2017) remains a matter of debate.

From school posters portraying student-becoming-scientist with dollars symbols titled "STEM leads to better careers" (STEM School, 2012) to policy documents prescribing the whats, whys and hows of STEM education, the modern science, technology, engineering and mathematics education paradigm is seen as a legitimisation of neoliberal hegemony by Matthew Weinstein, David Blades and Shannon Gleason (2016). These researchers argue that STEM obsession with global competition reduces school science to a mere career education. They claim that neoliberal "STEM'ification" of education changes the way students see and frame scientific problems, leading to prioritisation of market-driven solutions to problems of democracy and social justice (Weinstein et al., 2016). Clayton Pierce (2013) questions utilitarian education policies by expanding the notion of human capital. Drawing on the Michel Foucault terminology he theorises biocapitalism - a capitalist accumulation strategy commodifying, subjectifying and exploiting human bodies and nonhuman living beings. Subsequently, scientific and technological advances are seen as a potential value to be extracted from students. In order to extract this value, compulsory cultivation of students' productive capacities is being utilised via education. This author sees STEM as the pinnacle of biocapitalist education, which he brands as extractive schooling (Pierce, 2013).

Dana Zeidler (2014) challenges the prevailing assumption of STEM as a panacea for preparing the next generation of informed citizens. He asks two fundamental questions: how do STEM educational experiences play out through life-long development of a student, and more importantly, what do these experiences leave out (Zeidler, 2014)? Analysing STEM policy documents he claims that orthodoxically positivist and technocratic nature of STEM initiatives separates values from facts and leaves broader sociocultural and political contexts 
out of STEM education (Zeidler, 2014). By doing so, we make science education impersonal, irrelevant and removed from students' immediate lives; moreover, it forms decontextualised scientific literacy which nurtures mainly technical competences leaving out social, political or environmental responsibility (Zeidler, 2014). This author offers a sociocultural perspective of STEM enacted through pedagogical model called Socio-Scientific Issues (SSI) as a solution.

This section has attempted to provide a brief overview of the literature relating to the shortcomings of utilitarian STEM education. While there is no doubt that hegemonic STEM discourse affects pedagogical practises, the present paper has been inspired by another paradoxical, yet mostly ignored, aspect of STEM debate - there are big doubts about STEM labour supply shortage. What follows is a brief overview of some of these claims.

\section{STEM LABOUR SHORTAGE CONTRADICTION}

Emma Smith and Patrick White (2019), based on their analysis of STEM degree holder career trajectories in the UK labour market, suggest that there is no overall shortage of STEM graduates; on the contrary, the majority of STEM graduates never work in highly skilled STEM jobs. Analysing patterns of participation in STEM degrees between 1988 and 2012, these researchers prove that the many costly initiatives to increase the number of students studying 'shortage' STEM subjects have not worked" (Smith \& White, 2019). They state that only one third of non-medical STEM graduates have STEM jobs 6 months after graduation and demonstrate that while half of engineering graduates eventually get STEM jobs, the rest of STEM field graduates are struggling to get highly skilled positions in STEM workforce (Smith \& White, 2019).

Andrew Norton and Beni Cakitaki (2016) analysed Australian STEM majors in the labour market and identified that Australia has many more science graduates than its labour market can absorb. These researchers claim that with the exclusion of engineering, the rest of STEM majors in Australia are pushed into an overcrowded labour market (2016, p. 98). Specifically, science field students struggle in finding full-time work, scoring 17 percentage points below the national average in overall employment (Norton \& Cakitaki, 2016).

Hal Salzman and Lieff Benderly analysed assertions of US STEM labour shortage and pointed out the opposite - that the supply of graduates is substantially larger than needed, specifically, between 40 to 100 percent more STEM majors are produced than are hired into STEM occupations each year (2019). Authors claim that the accusation of an insufficient K-12 pipeline inhibiting STEM labour does not hold true. They highlight that only about $8 \%$ of a high school cohort is enough to maintain the historical share of STEM college majors (Salzman \& Benderly, 2019). Similar findings of US Census Bureau, report that 74 percent of STEM bachelor's degree owners are not employed in STEM occupations (US Census Bureau, 2014). Nevertheless, STEM labour shortage narrative continues to signify STEM education discourse. 


\section{LITHUANIAN STEM LABOUR SHORTAGE NARRATIVE}

Likewise, the narrative surrounding LithuanianSTEM education is alarmist:

There is a shortage of specialists in the engineering industry - the need is growing while the number of students willing to study decreases" (ELTA 2019) states one of the many headlines encouraging future students to choose degrees in STEM. "Promises made to investors will be difficult to keep (...)"

worries Jurgita Šiugždinienè (2018) in a weekly national Business News journal analysing decreasing numbers of engineering and technology students (2018). The dire situation in the Lithuanian economy regarding qualified STEM professionals is revealed by investor consultancy service company 'Invest Lithuania', arguing that 70 percent of Lithuanian employers face a shortage of qualified STEM workers (Invest Lithuania, 2014). Another text by Government Strategic Analysis Centre showcases top highest starting salaries of recent graduates, revealing that highest salaries are those of STEM diploma holders (STRATA, 2019). The panorama drawn by the many governmental and nongovernmental officials has a clear message: STEM graduates are needed, STEM majors are financially superior, and career guaranteed.

Echoing foreign trends, Lithuanian education policy makers are on the same STEM shortage hype-train, and reforms are full steam ahead. Recently, Lithuanian national ministry of science, education and sports reformed the higher education state grant programme list. The public funding for social sciences, humanities and arts was cut down, transferring financing to engineering, sciences, information and communications technology (ICT) study fields. In their public announcement, the ministry states: "according to labour market trends, the number of state grants for programmes in engineering, technology, computer science and physical sciences was increased around 50 percent in collages (...)" (ŠMSM, 2018). While majority of these new positions remained vacant, the fact that respectively higher numbers of social sciences, arts or humanities students had to pay for their education out of their own pockets remained unsaid. The statement continues declaring that the vacant STEM positions were a consequence of insufficient secondary education pipeline. This rhetoric increases the already ongoing STEM popularisation projects in general education e.g.: Project "ICT in primary and pre-primary education" (implemented in 100 schools); Pilot project "experiments of integrated science education curriculum" (conducted in 79 schools); Purchase of laboratory equipment for STEM classrooms (533 schools); Millions of euros dedicated for STE(A)M science promotion centres in ten municipalities; etc.

That's not to say that these initiatives are redundant. There is no doubt that the classroom equipment for STEM education in Lithuania is lacking (according to researchers only $2 \%$ of $4^{\text {th }}$ graders and $11 \%$ of $8^{\text {th }}$ graders attended schools having science labs) (Želvys, Dukynaitè, \& Vaitekaitis, 2018). Therefore, additional resource dedication is laudable. Likewise, it is intuitive that the fourth industrial revolution and modern digitalised world requires relevant skills and competences, thus integrated STEM curriculum initiatives are welcome. More- 
over, significance of STEM knowledges to our individual as well as collective lives is tremendous. Thus educational policies devoted to STEM sciences are, no doubt, timely. Nonetheless, portraying STEM education mainly as personal or national economic growth could reduce learners to a mere resource and science education to instrumental learning of marketable skills. On one hand, it could be considered dehumanising, on the other disserving the educational potential integrative STEM education holds. Taking into consideration the contradictory labour supply and demand research described earlier, also the critique of underlying utilitarian rationale of STEM, it is of value to investigate the STEM supply shortage narrative more closely.

In the light of above mentioned, the principal objective of this paper is to explore perceived shortage of Lithuanian STEM labour force supply by assessing STEM graduates' occupational destinations one year after graduation and average salaries in those professions. While limited in scope, this type of analysis can give insights about soundness of ongoing educational reforms and inform future students, who are, at the present, encouraged to study STEM degrees based on the premise of better labour market outcomes.

\section{METHODOLOGY}

One of the most common procedures for determining the supply of specialists for industry is descriptive statistical analysis of: a) distribution of employed graduates by profession; b) average monthly income in selected professions.

\section{Definitions}

Throughout this paper, the term "STEM majors," "STEM degrees," "STEM graduates" will refer to higher education degree holders in STEM fields of study. Unfortunately, STEM fields of study remain a poorly defined term (Ritz \& Fan, 2014). Some organisations and researchers use a "wide" STEM study field definition ("core" STEM subjects like science, technology, engineering and mathematics with addition of medical and healthcare; agriculture, fisheries and forestry; construction and architecture; social/behavioural sciences and arts broad study fields) (UKCES, 2011), (UK Parliament, 2012), (US National Science Foundation, 2014), (Koonce, Zhou, Anderson, Dyah, \& Conley, 2011). Other organisations narrow down STEM fields of study for easier comparability. For example, European Centre for the Development of Vocational Training (Cedefop) excludes many of the abovementioned fields except architecture, construction and "core" STEM subjects (EU Skills Panorama, 2014). A most recent European Commission initiated report narrows down STEM definition even more by excluding Architecture/Construction and Healthcare study fields. The report argues that "architectural studies in some EU countries have very limited connection and relevance to core STEM sectors and occupations" (Shapiro, Østergaard, \& Hougaard, 2015). In the light of contradicting defi- 
nitions, this paper will use the narrowest, but least inconsistent definition of STEM fields of study that is universally agreed as being "core" STEM. These fields are presented based on ISCED (2011) Fields of Education classification at a two-digit level detail:

- Life sciences (ISCED 42),

- Physical sciences (ISCED 44),

- Mathematics and statistics (ISCED 46),

- Computing (ISCED 48),

- Engineering and engineering trades (ISCED 52),

- Manufacturing and processing (ISCED 54).

In accordance with these STEM fields and above-mentioned reports to European Commission (Shapiro et al., 2015), (Tornese, 2017) "STEM occupations" or "STEM positions" in this paper will refer to these occupational categories (classified based on International Standard Classification of Occupations (ISCO-08)):

- Science and engineering professionals (ISCO 21),

- Information and communications technology professionals (ISCO 25),

- Science and engineering associate professionals (ISCO 31),

- Information and communications technicians (ISCO 35).

It is worth noting that according to International Standard Classification of

Occupations (ISCO-88) there are 4 occupational levels corresponding to these ISCED educational requirements: first level - ISCED 1; Second level - ISCED 2, 3 or 4; Third level - ISCED 5; Fourth level - ISCED 6, 7, 8. First and second level occupations are considered low skill while third and fourth - high skill level). Only high skill level occupations (requiring tertiary education) are considered STEM jobs.

\section{Dataset sources and selection:}

The dataset of student distribution by profession one year after graduations is publicly available at the website of Consortium for the Students and Graduates Career Management Information System of Lithuanian Higher Education Institutions (https://karjera.lt/). The average insured income by age group in the profession is accessed at the Government strategic analysis centre's (STRATA) website (https://strata.gov.lt/).

All available tertiary education levels (ISCED levels 6-8) of STEM Fields, branches and programs with graduates in 2017 were chosen for analysis, including: Bachelor's, Master's and Doctoral levels.

Data from 25 out of 43 state and private higher education institutions was available. Graduates of 2017 were chosen in order to analyse their distribution by profession, at the moment of investigation no such data was available for later years.

Data of the average insured income in the corresponding occupation by age group describe average insured monthly income in euros (EUR) (here and hereafter before taxes) in the occupations of relevant age group (20-30-years-olds). 


\section{Sample}

In 2017 there were 27684 tertiary education graduates in 43 higher education institutions. The graduate career tracking is performed in 25 of them resulting in 16777 monitored graduates that represent $60 \%$ of all cohort in a given year. Data includes only graduates that are employed in Lithuania. Unemployed, self-employed or emigrated graduates are not in the original source data. After applying STEM fields of study criteria described earlier, 22\% $(n=3720)$ out of 16777 graduates fall under the category of STEM graduates. This survey was done 2 years after this cohort graduated, giving them one year of labour market experience.

The following parts of this paper move on to describe occupational distribution of these STEM field graduates followed by broad, narrow and detailed study field analysis, continuing with exploration of average monthly income of 20- to 30-year-olds in corresponding professions and finishing with conclusions, discussion and research limitation outline. As a supplement to this paper, a dynamic interactive visualisation was created using Power Bi software. It can be accessed online at https:/ / tinyurl.com/qwatmda.

\section{FINDINGS}

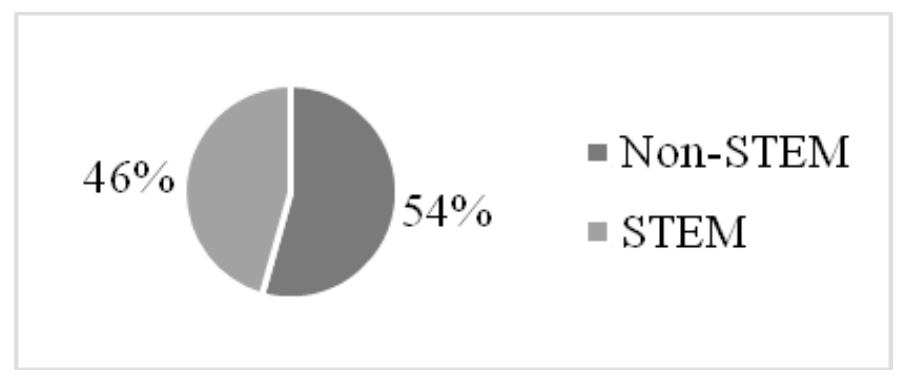

Fig. 1. Distribution of STEM graduates to STEM or non-STEM positions 12 months after graduation (percentage)

Source: Consortium for the Students and Graduates Career Management Information System of Lithuanian Higher Education Institutions (https:/ / karjera.lt/).

What were the professions Lithuanian STEM graduates held 12 months after finishing their training? This section examines distribution of employed graduates by STEM or non-STEM positions. The claim that the Lithuanian education system is not supplying sufficient amount of STEM majors for its national industries can be reasonably questioned, given that, majority ( $54 \%$ $\mathrm{n}=2023$ ) of all STEM degree holders do not work in jobs they have been trained for (Fig 1). 


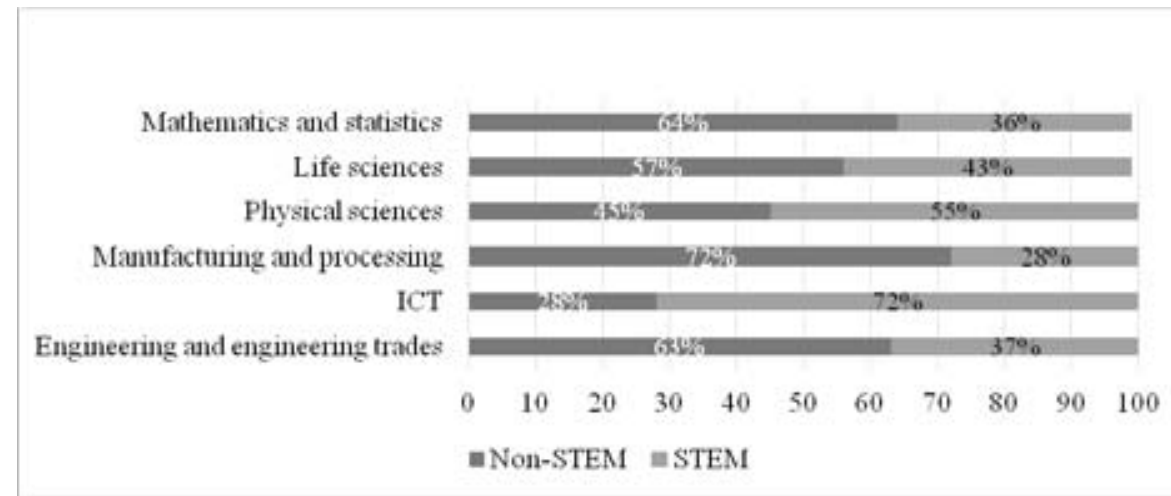

Fig. 2. Distribution of STEM graduates to STEM or non-STEM positions by narrow study field (\%).

Source: Consortium for the Students and Graduates Career Management Information System of Lithuanian Higher Education Institutions (https://karjera.lt/).

As illustrated above, 12 months after the graduation the majority of Engineering and engineering trades, Mathematics and statistics, Life sciences and vast majority of Manufacturing and processing along with half of Physical sciences graduates did not have an occupation considered STEM. The one exception is Information and Communication Technologies (ICT) graduates with only $28 \%$ of non-STEM workers. Why do we see only 4 in 10 STEM graduates employed in STEM one year after graduation? What does the remaining majority do? As will be shown further, while a significant part of them work as high skill level Professionals, Managers or Technicians and associate professionals in non-STEM jobs, the rest could be considered overqualified (employment in job positions not making full use of graduate level of knowledge, skills and competencies).

\footnotetext{
Natural Science, mathematics, statistics

Computing

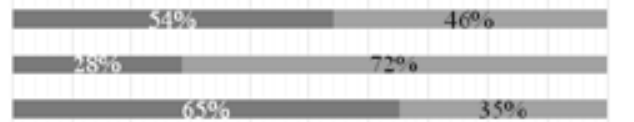

Engineering, manufacturing and processing

$0 \% \quad 10 \% 20 \% 30 \% \quad 40 \% \quad 50 \%, 60 \% \quad 70 \% 80 \% 90 \% 100 \%$

$=$ Non-STEM $=$ STEM

Fig. 3. STEM graduate distribution to STEM or non-STEM positions by broad study fields (\%).

Source: Engineering, manufacturing and processing broad study field (ISCED 52, ISCED 54) excludes Architecture and building (ISCED 58). Data source: Consortium for the Students and Graduates Career Management Information System of Lithuanian Higher Education Institutions (https://karjera.lt/).
} 
While Engineering, Manufacturing and Processing graduates represent majority $(56 \% n=2097)$ of all STEM degree holders in the cohort, we can identify that only $35 \%(n=732)$ of them work as STEM professionals or technicians and associate professionals (see Fig. 3). The remaining 65\% ( $n=1365)$ are distributed into high skill level and low skill level non-STEM workers.

The high skill non-STEM workers with engineering diploma were Advertising and marketing professionals, Policy administration professionals, Administrative and executive secretaries etc. The remaining two thirds of non-STEM workers with degrees in engineering, manufacturing or processing were occupying low skill jobs that do not require tertiary education (I, II skill level occupations usually require only secondary or vocational school diploma (ISCED $2,3,4)$ ) with majority of Transport engineering, Food and Beverage technologies, almost half of Electronic engineering detailed field graduates getting positions as Motor vehicle mechanics and repairers, Shop sales assistants, Electrical mechanics and fitters etc. (Refer to online supplementary material slide 2 for full list). This effectively renders 4 out of 10 Engineering, manufacturing and processing graduates as overqualified.

If we could focus for a moment on an average monthly income (Fig. 4), we could identify that most Engineering, manufacturing and processing graduates that do not work in STEM earn less than national monthly average income. According to the Lithuanian Department of Statistics average gross earnings (monthly) 2018 Q1 the national average was 887.8 EUR in the whole economy including individual enterprises). As could be expected, higher skill level requirements in professions are compensated more generously. The ones who do manage to exceed national monthly average salary margin are the ones who secure STEM jobs (35\% of broad field). They get compensated up to 156 EUR more. In an economy where the minimum monthly wage in Q1 2018 was 400 EUR, this could be considered as a substantial enough increase for young people to strive for. Most successful Engineering and engineering trades specific field graduates in terms of monetary reward are those of Aerospace engineering and Production and manufacturing engineering, with diploma holders on average earning 1060 and 952 EUR accordingly (refer to slide 2 of online supplementary material for other study fields). Manufacturing and processing narrow field graduates are less financially successful. The highest average salaries in this narrow field are those of Materials technology and Minerals technology graduates with an average income of 853 and 850 EUR respectively. Neither reaches the average national monthly wage margin. Manufacturing and processing narrow field graduates who do not manage to get a STEM job $(72 \%$ of the field) on average earn 653 EUR presenting Manufacturing and processing narrow study field as least financially successful out of all STEM fields. 


Non-STEM
STEM
National avarage $2018 \mathrm{Q1}$
(887 EUR)

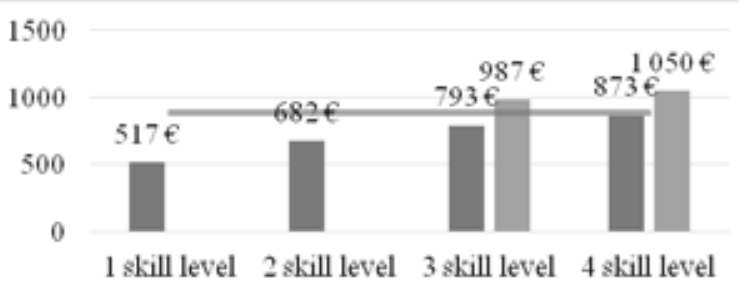

Fig. 4. Engineering, manufacturing and processing graduates' average monthly income by skill level required in professions taken 12 months after graduation.

Source: Engineering, manufacturing and processing broad study field (ISCED 52, ISCED 54) excludes Architecture and building (ISCED 58). Average monthly income describes average insured monthly income in euros before taxes in the corresponding occupations of 20- to 30-year-olds, source: Government strategic analysis centre (STRATA) (https://strata.gov.lt/); National average income as of Q1 2018 (887 EUR before taxes), source: The Lithuanian Department of Statistics https:/ / www.stat.gov.lt/en; Skill level as defined by International Standard Classification of Occupations (ISCO-88).

Moving on to Natural science broad field we observe that less than half $(46 \% \mathrm{n}=354)$ of these graduates secure positions in STEM (Fig. 5) Looking at narrow field level, the numbers of Physical sciences are higher $(54 \%, n=168$ of narrow field in STEM), but Mathematics and statistics, also Life sciences degree holders have substantially lower counts in STEM jobs (respectively $35 \%, 43 \%$ in STEM).

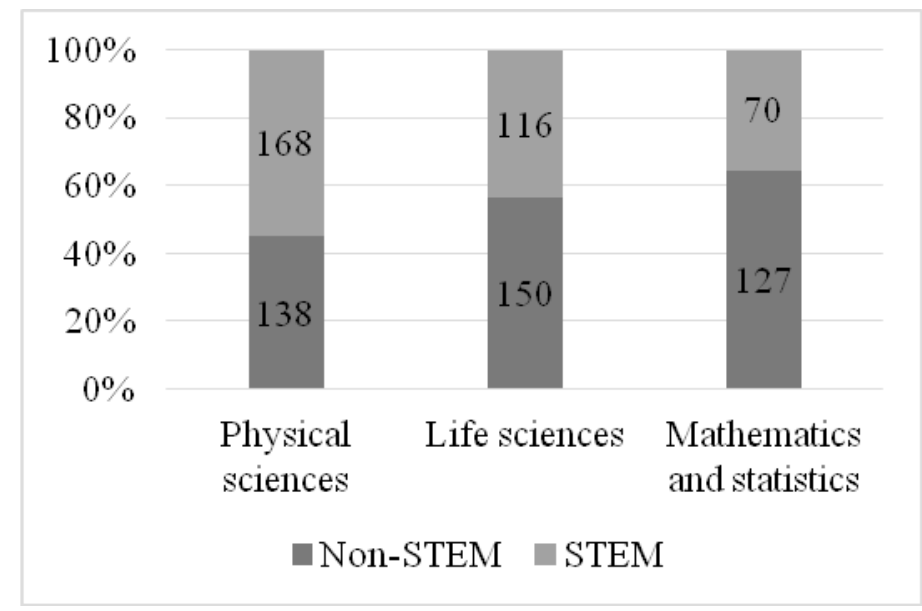

Fig. 5. Number of Natural Science graduates by narrow study fields and STEM or non-STEM occupation.

Source: Consortium for the Students and Graduates Career Management Information System of Lithuanian Higher Education Institutions (https:/ / karjera.lt/)

If we could focus for a moment on occupational skill level in taken positions (Fig. 6), it would be clear that Natural science field has only $17 \%$ of its gradu- 
ates in low skill level positions, the remaining share secure high skill jobs. It is worth mentioning that we find zero Mathematics and statistics degree holders in lowest skill level jobs, and almost 4/10 in highest skill positions in non-STEM occupations (Management and organisation analysts, Advertising and marketing professionals and Financial analysts). In general terms, this means that while comprising $20 \%$ of grand total STEM graduates $(n=769)$, the broad study field of Natural Science has the biggest share of graduates doing highest skill non-STEM jobs per all broad fields. It could be speculated, that because of the lower monetary reward, this is not a voluntary choice. Given the limitations of this paper a more comprehensive analysis of potential reasons for this is left out. The following is a brief description of the most popular professions and an average income by skill level in occupations taken by Natural Science graduates 12 months after graduation.

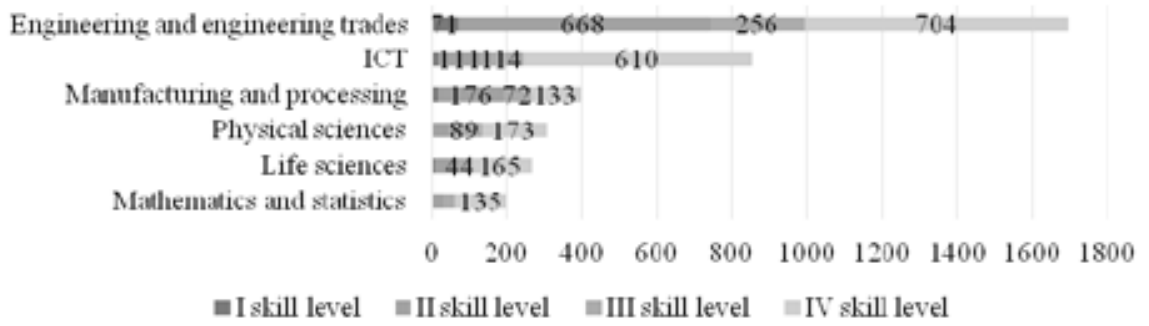

Fig. 6. Distribution of graduates by narrow study fields and occupational skill level. Source: Consortium for the Students and Graduates Career Management Information System of Lithuanian Higher Education Institutions (https://karjera.lt/); Skill level as defined by International Standard Classification of Occupations (ISCO-88).

The most popular occupations among Natural Science graduates in STEM were: Biologists, botanists, zoologists and related professionals, Chemists, Chemical and physical science technicians, while the most popular non-STEM jobs were: Advertising and marketing professionals, Management and organisation analysts, Shop sales assistants. For a detailed list refer to online supplementary material slide 2. Natural science graduates similarly to Engineering, manufacturing and processing majors do not reach average national wage if job is outside STEM sector. On a narrow study field level there is an exception - mathematics and statistics. Graduates of this narrow study field earn salaries higher than national average in STEM as well as in non-STEM jobs. The highest financial reward is received by Mathematics and statistics majors taking STEM duties as Software developers, System analysts, Software and applications developers and analysts not elsewhere classified reaching monthly salaries up to 1732, 1487, 1142 EUR accordingly. In non-STEM jobs graduates of mathematics and statistics earn on average 959 EUR in IV level skill jobs and 899 EUR in III skill level jobs. Physical science narrow field degree holders on average earn 1017 EUR in STEM jobs and 853 EUR in non-STEM, leaving 
Life sciences narrow field as least financially rewarding with 928 EUR average monthly income in STEM jobs and 709 EUR in non-STEM. This effectively renders Life sciences as second least financially attractive narrow study field bypassing only manufacturing and processing narrow field. For a detailed list of incomes refer to online supplementary material slide 2 .

Next figure displays the broad study field holding second largest share of all STEM majors in the cohort $(22 \% \mathrm{n}=854)$ and having the biggest proportion (71\%) of high skill STEM occupations per broad field - Computing sciences. Most often these graduates work as Software developers, Applications programmers or Software and applications developers and analysts not elsewhere classified. Successful employability and labour market demand of ICT graduates is evident as this broad science field is best financially compensated out of all STEM broad study fields. Graduates of Computing sciences take positions on average earning 1201 EUR in STEM jobs, and 772 EUR in non-STEM (Fig. 7). It's worth noting that IV and III level occupations taken by ICT graduates earn more than national average even in non-STEM occupations (Advertising and marketing professionals, Information and communications technology sales professionals, or Management and organisation analyst positions).

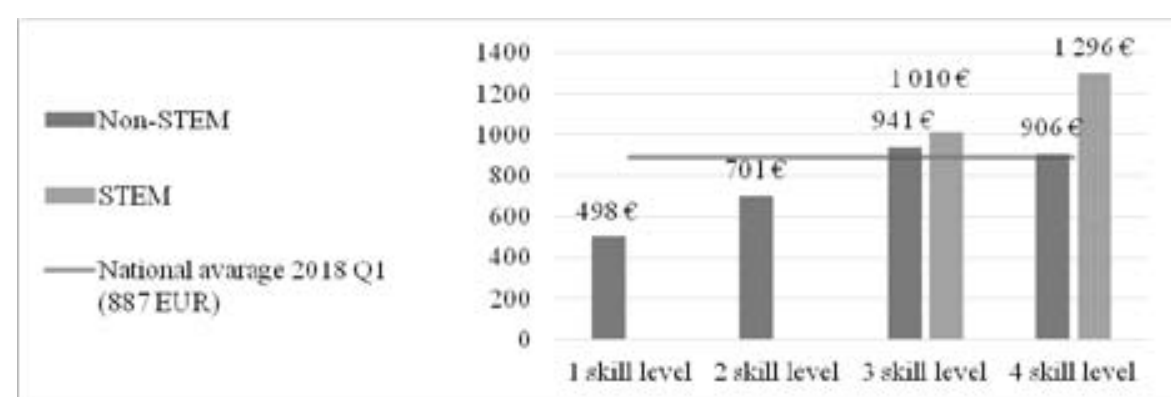

Fig. 7. Computing sciences graduates' average monthly income by skill level required in professions taken 12 months after graduation.

Source: Average monthly income describes average insured monthly income in euros (EUR) before taxes in the corresponding occupations of 20- to 30-year-olds, source: Government strategic analysis centre (STRATA) (https:/ / strata.gov.lt/); National average income as of Q1 2018 (887 EUR before taxes), source: The Lithuanian Department of Statistics https:/ / www.stat.gov.lt/ en; Skill level as defined by International Standard Classification of Occupations (ISCO-88).

What can be seen when comparing all STEM narrow study fields by average income of 20- to 30-year-olds in corresponding jobs (Fig. 8) is that only Computing sciences and Mathematics and Statistics (27\% of grand total STEM graduates) get jobs with median income higher than national average (1 124 and 1012 EUR accordingly). The rest narrow study fields, in terms of median monthly income line up as follows: Engineering and engineering trades (854 EUR), Physical science (767 EUR), Life sciences (767 EUR), Manufacturing and processing (682 EUR). But if one to group wages of STEM jobs and compared it with non-STEM jobs, a gap of 365 EUR would be evident, (median income of all STEM positions is 1124 EUR, while non-STEM 759 EUR.). 


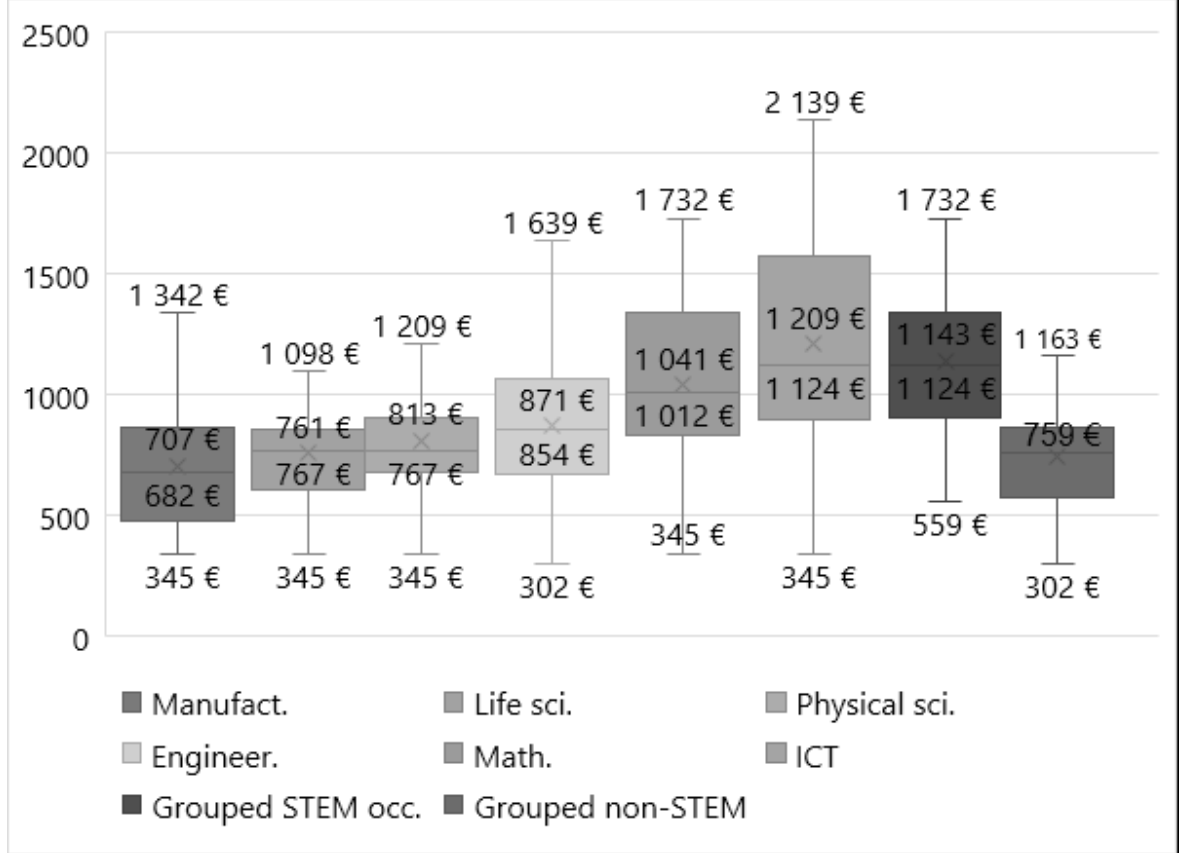

Fig. 8. Maximum, minimum, median and mean monthly income by narrow study fields and grouped STEM or non-STEM occupations.

Source: $\mathrm{X}$ inside boxplot for mean, line for median. Manufact.- Manufacturing and processing; Life sci.- Life sciences; Physical sci.- Physical sciences; Engineer- Engineering and engineering trades; Math.- Mathematics; ICT- Information and communications technology; Grouped STEM occ.- all abovementioned study field majors working in STEM jobs; Grouped non-STEM - all abovementioned study field majors working in non-STEM jobs. Monthly income describes average insured monthly income in euros (EUR) before taxes in corresponding occupations of 20- to 30-year-olds, source: Government strategic analysis centre (STRATA) (https:/ / strata.gov.lt/).

Responding to the claims of STEM jobs earning superior salaries an overview of Social science, Humanities and Arts graduates $(n=9344)$ taken profession's average income was carried out (refer to slide 5 in online complementary visualisation). The comparison revealed that median income in professions taken by Social sciences, Humanities and Arts broad study fields are 778, 778, 692 EUR accordingly. This illustrates that on the STEM degree side, only Computing broad field is substantially better compensated (median income 1124 EUR), the rest, Natural science and Engineering, Manufacturing and processing broad fields (805 and 829 EUR median income accordingly) are in the same ballpark as Social sciences, Humanities and Arts concerning monetary compensation. The last part of the analysis describes the distribution of STEM and non-STEM graduates by detailed study fields and skill level.

Looking at non-STEM and STEM distribution between detailed study fields (refer to slide 3 in online complementary material) we can identify that most 
detailed fields generate graduates working in both - STEM and non-STEM jobs. There are also detailed fields with high disproportions. For example, Informatics, Health informatics or Software engineering detailed fields generate disproportionately high numbers of STEM workers, whereas some fields show the opposite tendency. E.g. Transport Engineering has six times more graduates working in non-STEM than STEM; Food and Beverage Studies and Food and Beverage Technology, also Environmental Sciences detailed fields generate up to 4 times more non-STEM workers than STEM. Physical geography has 3 non-STEM workers for every 1 in STEM. In Biology this number is 1 to 2.5, Zoology - zero STEM workers. Likewise, focusing at skill level distribution we can identify a wide variety. Looking at Physics, Physical geography, Chemistry and Geology detailed fields we can observe that no matter the STEM or non-STEM distribution, majority of graduates in these detailed fields do high skill jobs at III or IV complexity level. The same goes for Life sciences, where the Biology, molecular biology, biophysics and biochemistry, Microbiology or Genetics graduates are mainly doing highly qualified work in STEM as well as in Non-STEM. All Mathematics and Statistics, as well as Computing narrow study field graduates continue this trend. On the other side of the spectrum, we observe graduates taking positions in jobs not requiring higher education. Highest numbers of these graduates are observed in Transport engineering, Food and Beverage Technology and Food and Beverage studies detailed fields. These fields generate both, high numbers of low skill workers, and high numbers of non-STEM workers. Electronics and electrical engineering detailed study field has half of former students in high skill STEM positions, but the remaining half has exclusively low skill jobs. An in-depth comparison of a specific higher education institution training these graduates could shed light on whether this could be attributed to training quality, but this is out of the scope of this paper. What is clear, though, is that almost half of non-STEM workers are high skill professionals that undertake complex highest skill requiring tasks in sectors outside of their original training.

\section{LIMITATIONS}

In this investigation there are several sources for error. The study is based on a single cohort of STEM degree holders employed twelve months after graduation (2017-2018), a longitudinal study revealing occupational trajectories of this cohort over a longer period would be more revealing, but no such data was available. Another limitation is the fact, that data includes only employed graduates. Unemployed, self-employed or emigrated graduates are not reflected in the source data. The reader should also bear in mind that calculations of income are not tied to individual graduates, but to an average income received by 20- to 30-year-olds in professions occupied by these graduates. Also it must be noted, that III skill level occupations $(17 \%$ of grand total $((n=579))$ requiring short-cycle tertiary education (ISCED level 5) which is not and never was pre- 
sent in modern Lithuanian education system, renders most specialists in this category as an upgrade from ISCED 1, 2, 3 in the form of on-the-job training, or, as likely, a downgrade from ISCED 6, 7, 8. As there was no way to validate any of these versions, it was considered that III level skill professions can be regarded as STEM.

\section{CONCLUSIONS AND DISCUSSION}

In this investigation, the aim was to assess perceived shortage of Lithuanian STEM labour force supply by analysing STEM graduates' occupational destinations one year after the graduation and an average salary in those professions. The descriptive statistical analysis suggests there is no general shortage of STEM labour supply when talking about numerical shortage of STEM degree holders, as twelve months after graduation we observe 6 out of 10 STEM graduates not working in STEM.

More than half $(54 \%, n=2023)$ of STEM diploma owners are overqualified (having education, experience, or skills beyond the requirements of the job) or doing high skill jobs outside of STEM sector. Low skill level workers $(60 \%$ of all non-STEM workers, $\mathrm{n}=1194$ ) are not considered STEM because occupational positions they take do not require higher education (I-II skill level jobs. e.g. Automotive mechanics, Electrical mechanics and fitters, Electronics mechanics and servicers etc.). The high skill level non-STEM workers (40\% of non-STEM workers, $\mathrm{n}=829$ ) are Professionals, Technicians and associate professionals in non-STEM sectors (e.g. Natural science graduates working as advertising and marketing specialists or Civil engineers working as managers, etc.) $22 \%$ of all STEM graduates are high skill non-STEM workers.

The highest proportion of low skill workers per all narrow fields are identified in Manufacturing and processing (48\% of narrow field), followed by Engineering and engineering trades (43\% of narrow field). Most significant contributors of low skill workers at detailed study field level are Food and Beverage technology (55\% overqualified) and Transport engineering (63\% overqualified). Research also identified most high skill level non-STEM workers in the broad study field of Natural sciences. At narrow study field highest numbers of these graduates are found in Mathematics and Statistics followed by Life sciences and Physical science (accordingly 48\%, 34\%, 30\% per narrow field do high skill level jobs outside STEM). Due to practical constraints, this paper cannot provide a comprehensive analysis or explanations behind the supply and demand imbalance. Speculations could vary from employers, for any reason, choosing not to employ these graduates, to graduates choosing not to be employed. Full investigation of this is left for future.

The comparison of the monetary incentives revealed that 12 months after graduation STEM majors securing jobs in STEM get up to 365 EUR higher median salary than their counterparts in non-STEM jobs. While highest salaries are most likely received by ICT and Mathematics and Statistics narrow 
field graduates, the remaining majority usually does not reach national average salary margin and is compensated similarly to Social science, Humanities or Arts graduates.

It is also important that in terms of employment and median incomes significant variations between separate STEM study fields were observed. This draws us to suggest that instead of STEM acronym a specific skill or study field name should be preferred. STEM encompasses beautiful, and highly important modes of knowledge construction crucial for our future, but in the context of labour market this acronym is too ambiguous.

It is often believed that education systems are the bottleneck of economic growth and that by increasing the supply of STEM majors we will get more and better paid jobs. On the same premise, funding for education is reallocated, curricula are framed, and students are encouraged to choose STEM degrees. The results of this exploration provide insights suggesting that more than half of STEM graduates 12 months after graduation do not work in jobs they have been trained for. Hence, student persuasion to study STEM degrees based on better labour market outcomes is misleading and possibly unethical.

The principal theoretical implication of this paper is the acknowledgment that low STEM diploma holder employment in STEM does not necessarily signify a failing education system. Instead, it indicates that when measured against labour market success, education systems are failing. This does not imply that education systems are without problems, by no means. But rather than framing our educational policies within an economic paradigm, we ought to conceive the negative impact this discourse induces upon educational process in the first place. With this said, it can be argued that STEM graduates do not work in STEM not because of flawed education, but despite flawed education.

On one hand, this insight might provide support for policies promoting convergence of science education with the labour market to an even higher degree. On the other, a more radical proposition could be made - an embrace of multiple STEM career trajectories, including the non-STEM sector. We need apolitical scientists no more than we need scientifically illiterate politicians. If one agrees that our post-truth era problems are social, political and cultural before they are technical, the ongoing "STEMmania" (Sanders, 2009) in education is an opportunity to experiment and look for alternative ways of framing STEM education. These alternatives might include Science, Technology, Society and Environment or Sociopolitical Development in science education, Socio-Scientific Issues, Society Technology Studies or other transformative pedagogical approaches capable of nurturing critical thinkers and doers that societies need. What is clear, though, is that the present neoliberal STEM paradigm does not please the industries, nor does it realise the revolutionary potential integrated science, technology, engineering and math education hold. 


\section{REFERENCES}

[1] Chavatzia, T. (2017). Cracking the code: girls' and women's education in science, technology, engineering and mathematics (STEM). Retrieved August 20, 2019 from https://euagenda.eu/ upload/publications/untitled-137226-ea.pdf.

[2] Chesky, N. Z., \& Wolfmeyer, M. R. (2015). Philosophy of STEM education a critical investigation. New York: Palgrave Macmillan. doi: 10.1057/9781137535467.0001.

[3] Deming J. D. (2017). The growing importance of social skills in the labor market. The Quarterly Journal of Economics, 132(4), 1593-1640. doi: 10.1093/qje/ qjx022.

[4] Feder M. (2012). One decade, one million more STEM graduates. Retrieved December 2, 2019, from https://obamawhitehouse.archives.gov/blog/2012/12/18/ one-decade-one-million-more-stem-graduates.

[5] Gillmann B. (2018, November 28). Germany tech worker shortage gets worse. Retrieved December 2, 2019 from https://www.handelsblatt.com/today/companies/stem-skills-germany-tech-worker-shortage-gets-worse/ 23695034. html?ticket=ST-28919827-gWZM410hwy9vfe4e3nkY-ap1.

[6] Hong, O. (2017). STEAM education in Korea: current policies and future directions. Science and Technology Trends Policy Trajectories and Initiatives in STEM Education, 8(2), 92-102.

[7] ICF \& Cedefop. (2015). EU skills panorama 2014: STEM skills analytical highlight. Retrieved August 19, 2020, from https://skillspanorama.cedefop.europa.eu/sites/default/files/ EUSP_AH_STEM_0.pdf.

[8] Invest Lithuania. (2014). Kodèl Lietuvoje trūksta tiksliujų ir gamtos mokslu specialistų? [Why is there a lack of science specialists in Lithuania?]. Retrieved December 02, 2019, from https:/ / investlithuania.com/lt/naujienos/kodel-lietuvoje-truksta-tiksliuju-ir-gamtos-mokslu-specialistu/.

[9] Kearney, C. (2015). Efforts to increase students' interest in pursuing science, technology, engineering and mathematics studies and careers. Retrieved December 2, 2019, from http://www.voced.edu. $\mathrm{au} /$ content/ngv51728

[10] Koonce, D. A., Zhou, J., Anderson, C. D., Dyah, H. A., \& Conley, V. M. (2011). AC 2011-289: What is STEM? American Society for Engineering Education. Retrieved August 19, 2020, from https:// peer.asee.org/what-is-stem.

[11] Morgan, R., Kirhy, C., \& Stamenkovic, A. (2016). The UK STEM education landscape: a report for the Lloyd's register foundation. Retrieved December 2, 2019, from http://www.raeng.org.uk/ publications/reports/uk-stem-education-landscape.

[12] National es MINT Forum (2019). Auber uns. Retrieved 12 December 2019, from https:/ / www. national esmintforum.de/.

[13] Norton, A., \& Cakitaki, B. (2016). Mapping Australian higher education 2016. Grattan Institute.

[14] Pierce, C. (2013). Education in the age of biocapitalism: Optimizing educational life for a flat world. New Your: Palgrave MacMillan.

[15] Ritz, J. M., \& Fan, S. C. (2015). STEM and technology education: International state-of-the-art. International Journal of Technology and Design Education, 25(4), 429-451.

[16] Sanders, M. (2009). STEM, STEM education, STEMmania. The technology teacher, December/ January 2009, pp. 20-26. Retrieved 18 August 2020 from https://vtechworks.lib.vt.edu/bitstream/handle/10919/51616/STEMmania.pdf?sequence.

[17] Salzman, H., \& Benderly, B. L. (2019). STEM performance and supply: Assessing the evidence for education policy. Journal of Science Education and Technology, 28(1), 9-25.

[18] Shapiro, H., Østergaard, S. F., \& Hougaard, K. F. (2015). Does the EU need more STEM graduates? Final report. Retrieved 18 August 2020 from https://op.europa.eu/pl/publication-detail/-/ publication/60500ed6-cbd5-11e5-a4b5-01aa75ed71a1.

[19] Siugždinienė, J. (2018). Vaikščiojimas plonu ledu: inžinerijos ir technologijos mokslų studentu pavojingai mažèja [Walking on thin ice: Numbers of engineering and technology science students are dangerously declining]. Verslo žinios. Retrieved December 05, 2019, from https:// www.vz.lt/verslo-aplinka/2018/08/26/vaiksciojimas-plonu-ledu-galinciu-ir-norinciustudijuoti-inzinerijos-ir-technologijos-mokslus-pavojingai-mazeja.

[20] Smith, E., \& White, P. (2019). Where do all the STEM graduates go? Higher education, the labour market and career trajectories in the UK. Journal of Science Education and Technology, 28(1), 26-40. https://doi.org/10.1007/s10956-018-9741-5. 
[21] ŠMSM. (2018). Galutiniai prièmimo ị aukštąsias mokyklas rezultatai: jaunimas išgirdo darbo rinkos poreiki [Final results of admission to higher education: young people heard the call of the labour market]. Retrieved December 02, 2019, from https://www.smm.lt/web/lt/pranesimai_spaudai/galutiniai-priemimo-i-aukstasias-mokyklas-rezultatai-jaunimas-isgirdodarbo-rinkos-poreiki.

[22] STEM Learning (2018). About us. Retrieved 12 December 2019, from https:/ / www.stem.org. uk/.

[23] STEM School (2012). What is STEM education. Retrieved December 02, 2019, from https:// www.stemschool.com/articles/what-is-stem-education.

[24] STRAT. (2019). Populiarios specialybès lengvos karjeros pradžios negarantuoja [Popular specialities do not guarantee an easy career start]. Retrieved 4 December 2019, from http:// strata.gov.lt/lt/naujienos/8-naujienos/559-populiarios-specialybes-lengvos-karjeros-pradzi os-negarantuoja.

[25] Tornese, P. (2017). STEM4YOU(th). Deliverable report d2.2 stem qualification and job profiles report. Retrieved 18 August 2020 from http:/ / www.stem4youth.eu/wp-content/uploads / 2018/07/ STEM_D2.2_v2.0.pdf.

[26] UK Parliament. (2012). Science and technology committee - second report: higher education in science, technology, engineering and mathematics (STEM) subjects. Retrieved 18 August 2020 from https:// publications.parliament.uk/pa/ld201213/ldselect/ldsctech/37/37.pdf.

[27] UKCES. (2011). The supply and demand for high-level STEM skills, briefing paper, December 2011 7 UK. Retrieved 18 August 2020 from https://dera.ioe.ac.uk/13757/1/briefing-paper-thesupply-of-and-demand-for-high-level-stem-skills.pdf.

[28] US ICE. (2016). STEM designated degree program list effective. May 10, 2016. Retrieved December 2, 2019, from https://www.ice.gov/sites/default/files/documents/Document/2016/stem-list.pdf.

[29] US National Science Foundation. (2014). NSF Approved STEM Fields. Retrieved 2 December 2019, from https://www.btaa.org/docs/default-source/diversity/nsf-approved-fields-of-study.pdf?sfvrsn=1bc446f3_2.

[30] US Census Bureau (2014). Census Bureau Reports Majority of STEM College Graduate are not employed in STEM occupations. Retrieved 2 December 2019, from https://www.census.gov/ newsroom/press-releases/2014/cb14-130.html.

[31] Weinstein, M., Blades, D., \& Gleason, S. C. (2016). Questioning power: deframing the STEM discourse. Canadian Journal of Science, Mathematics and Technology Education, 16(2), 201-212. https://doi.org/10.1080/14926156.2016.1166294.

[32] Zeidler, D. L., Herman, B. C., \& Sadler, T. D. (2019). New directions in socioscientific issues research. Disciplinary and Interdisciplinary Science Education Research, 1(1), 1-9.

[33] Želvys, R., Dukynaitė, R., \& Vaitekaitis, J. (2018). Švietimo sistemu efektyvumas ir našumas kintančių švietimo paradigmų kontekste [Effectiveness and efficiency of educational systems in a context of shifting educational paradigms]. Pedagogy Studies/Pedagogika, 130(2). https:/ / doi.org/10.15823/p.2018.20. 